\title{
SPATIAL ORIENTATION AND THE PATTERNS OF THE TRADITIONAL SETTLEMENT IN THE EASTERN BALI: INVESTIGATING NEW TOURISM ATRACTIONS
}

\author{
I Dewa Gede Agung Diasana PUTRA* \\ Udayana University, Engineering Faculty, Department of Architecture, \\ Bukit Jimbaran Campus, Bali Indonesia 80361, e-mail: diasanaputra@unud.ac.id \\ Ida Bagus Gde WIRAWIBAWA \\ Udayana University, Engineering Faculty, Department of Architecture, \\ Bukit Jimbaran Campus, Bali Indonesia 80361, e-mail: ib_wirawibawa@unud.ac.id \\ Made Wina SATRIA \\ Udayana University, Engineering Faculty, Department of Architecture, \\ Bukit Jimbaran Campus, Bali Indonesia 80361, e-mail: wina.satria@unud.ac.id
}

\begin{abstract}
Citation: Putra, I.D.G.A.D., Wirawibawa, I.B.G \& Satria, M.W. (2020). SPATIAL ORIENTATION AND THE PATTERNS OF THE TRADITIONAL SETTLEMENT IN THE EASTERN BALI: INVESTIGATING NEW TOURISM ATRACTIONS. GeoJournal of Tourism and Geosites, 29(2), 614-627. https://doi.org/10.30892/gtg.29218-493
\end{abstract}

\begin{abstract}
The configuration of the traditional Balinese settlement is translated from a spiritual orientation related to the polarity concept. In this concept, the world is constructed upon opposite poles. It inspires spatial orientations and configurations, including the layout of villages. Since this spiritual orientation is based on geographical orientation, the highland, which stretches in the middle of Bali from east to west, causes the variations of spatial orientation system. This system produces the variations of spatial orientation patterns between the southern and northern. This system also generates a pattern's variation in many villages in the eastern part of Bali. This uniqueness influences the traditions of the communities, including the pattern of the architectural setting and the traditional settlement pattern. This uniqueness can be used as a means to present their identity and in the tourism economy can attract tourists. However, the variations have not been investigated yet, so tourists, even the local people, have not been aware of the uniqueness. In order to investigate this uniqueness, this paper examined the pattern of some villages in the eastern part of Bali. It uses architectural examination and spatial stories of people's activities as a method of investigation. This method involved architectural documentation, visual analysis, and narratives of people's cultural activities. This paper states that the geographical orientation is the impotent component to create the settlement pattern. The traditional settlement patterns of each village vary even though the villages are located close together.
\end{abstract}

Key words: Spatial orientation, geographical condition, landscape of Bali

\footnotetext{
* Corresponding author
} 


\section{INTRODUCTION}

Spatial orientation is an essential aspect of configuring the space of residential areas and traditional houses in Bali. In general, the traditional spatial orientation in Bali, kaja-kelod and kangin-kauh, is harmonized with a spatial orientation that applies globally (north-south and east-west). Kaja means toward the mountain and kelod means toward the sea. On the other hand, the direction of kangin-kauh is aligned with the eastwest direction. Its aligned position and the opposite poles are an essential aspect in determining the direction of sacred-profane spaces and certain gods occupy each direction. This spatial and spiritual orientation is used as a basis for settlements and traditional housing in Bali in general. This basic spatial pattern for settlement is to produce harmonious spaces for occupants in which natural and built environments, creativity and spiritual and other components of people's life become a grand orchestra (Gupta, 2017). However, some villages, especially in eastern Bali, have unique and only local directions of kaja-kelod and kangin-kauh. The uniqueness of this spatial orientation has the potential to influence and create unique and specific variations in the patterns of space for traditional residential areas in the region. As other traditional settlements that tried to address the topography conditions (Vaisakh \& Sood, 2017), this orientation concept is also influenced by the condition of the mountains of Bali, where the highlands are located in the center of the island, which extends from west to east.

This topography condition causes Bali is divided into two parts, namely southern and northern Bali and kaja and kelod to change depending on location. Kaja is north and kelod is south in the southern part of Bali and vice versa. On the other hand, kangin and kauh are fixed directions where kangin is the direction of the sunrise and kauh is the direction of the sunset. However, some areas in the eastern part of Bali, especially in villages located around Mount Bisbis (Lempuyang), have different orientation directions. Unlike villages in general that refer to the highlands in the central part of Bali, which stretches from west to east, the villages in this region are oriented to two mountains (Mount Bisbis and Seraya), which are not too high but have an essential meaning (Wassmann \& Dasen, 1999). In order to explore this orientation system, a based line survey was undergone to inventory the pattern of the settlement and housing. This inventory and interviews with the occupants are the way to reconstruct the unique and specific pattern of the traditional settlement and houses in this area (Putra et al., 2017).

The existence of a unique and specific spatial orientation that only applies locally is a tradition that shows cultural diversity in Bali. It is exciting things to deeply explore to understand the influences of spatial conception and patterns and the arrangement of spaces in traditional villages in the Eastern of Bali. This exploration can be an effort to inventory cultural textures and specific architectural practices, as well as reveal and explore the diversity of architecture in Bali and Indonesia. The uniqueness of this architecture can also be used and developed as one of the new tourist attractions in Bali. Therefore, the uniqueness of this region can also be the first step and new research fields not only related to the world of architecture but also associated with other fields such as anthropology, cultural arts and social structures of society and the field of tourism. Furthermore, this can be developed to support local wisdom-based tourism.

\section{TRADITION AND CONCEPT OF SETTLEMENT AND HOUSE}

Balinese traditional settlements and housing are one manifestation of the Balinese culture and traditions. Its settlements and housing reflect the broad experiences of the past and the inheritance of cultural aspects. These cultural aspects can be seen as a resource for creating a cultural identity (Hall, 1990; Derek \& Japha, 
1991; Proshansky et al., 1983). This identity expresses the traditions and cultural similarities between members of the community and expresses differences with those who are not members (Brubaker \& Cooper, 2000). Settlements, houses and their traditions are interrelated and bequeathed from generation to generation. A vernacular building including houses and residential areas are considered as an intersection of the bequest of property and traditions (Lozanovska, 2011). Balinese traditional settlements and housing is a space that shows that the world is divided into two opposite poles, the nature associated with the divine and the lower realm (nether). The upper realm is a sanctified world, while the underworld is profane (Hobart et al., 2001; Eiseman, 1989). Furthermore, between the two poles above, there is a space that is called madyapada/ mertyapada as a space for living beings (Hobart et al., 2001; Swellengrebel, 1984).

Balinese people believe that they have a religious philosophy in maintaining harmonious relations with God, human beings and protecting the environment. This philosophy is called tri hita karana (Hobart et al., 2001). This philosophy inspired other concepts from the physical division of the universe to the physical divisions of living things such as the concept of tri loka and tri angga. The concept of tri loka includes the upper realm for God (swah loka), the middle world for living beings (bwah loka) and the underworld (bhur loka). The concept of tri angga includes utama, madia and nista or head, body and feet (Eiseman, 1989).

The orientation concept in most villages in Bali is influenced by the geographical condition of Bali. The village (Figure 1) is divided into three parts. The sacred direction (utama) is located in the highland/mountains called kaja. For Balinese, the highest mount (Mount Agung) is the most sacred place. The opposite direction (nista) is kelod meaning the seaward (Gelebet, 1996; Rigg, 1996). In between the two opposites direction is the intermediate world for human beings (madya).

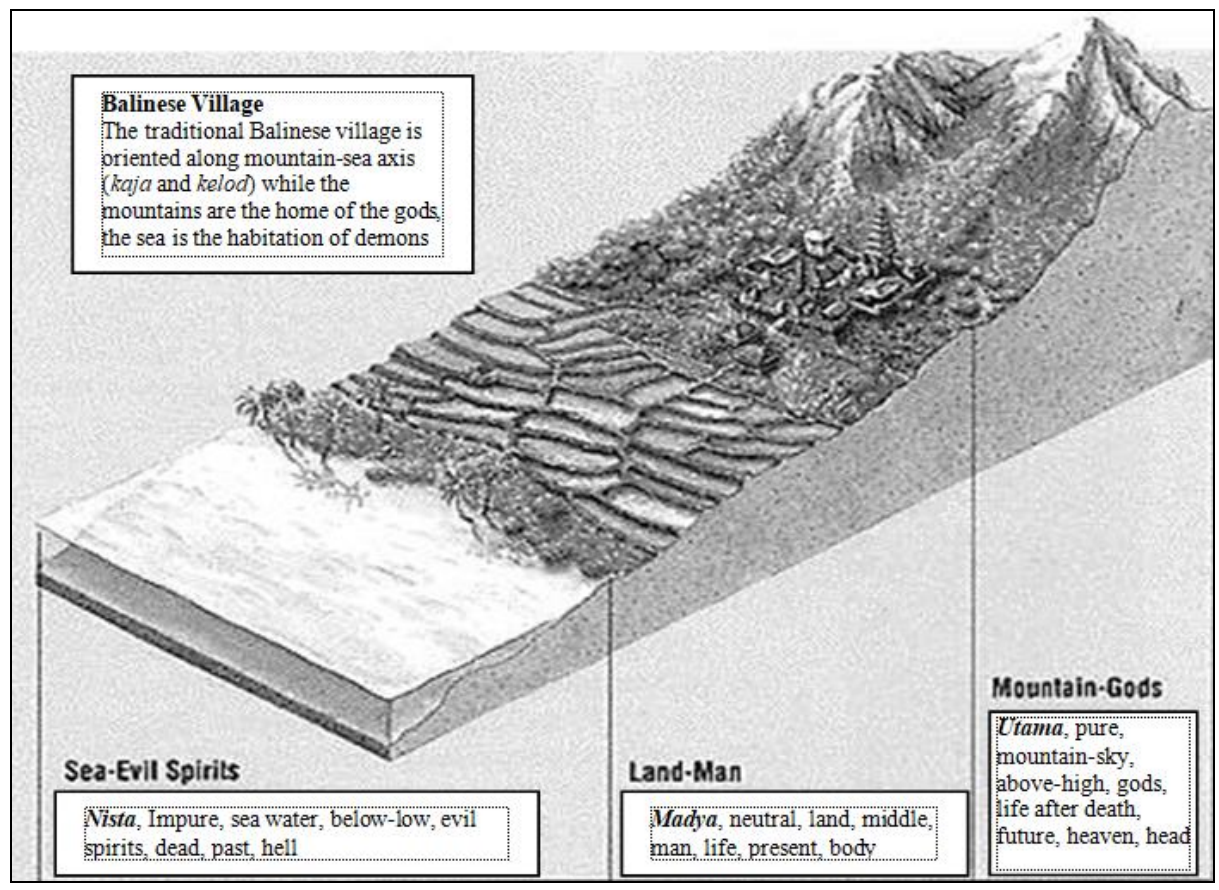

Figure 1. The Concept of Balinese Villages (Source: Rigg, 1996) 
However, most villages of Bali use the highland that is stretching from east to west in the middle of Bali, as the main direction for a sacred place. This topography condition causes kaja and kelod to change depending on location. The spatial orientation in Bali is then divided into two parts, namely southern and northern Bali. Kaja is north and kelod is south in the southern part of Bali and vice versa. On the other hand, kangin and kauh are the fixed directions where kangin is the direction of the sunrise and kauh is the direction of the sunset (Figure 2) (Budiharjo, 1986; Gelebet, 1986; Meganada, 1990).

Kangin, where the sun rises that brings light and life, is the sacred direction whereas, on the contrary, kauh, where the sunset is the profane region (Hobart et al., 2001). The two main directions, kaja-kelod and kangin-kauh, are a coordinate system and orientation, ritual behavior and the arrangement of social spaces (Hobart et al., 2001). However, some areas in Bali have different orientation directions. Some villages are oriented to mountains near the villages, which are not too high but have an essential meaning. This area includes several villages, such as Seraya Village in the south.

In this village, like other villages in south Bali, kaja is north and kangin is east. However, other villages around it showed different things. Kaja in each village remained oriented to the top of the mountain. Therefore, the direction is different in many places. Other villages in Bali have the direction of kangin and kauh fixed. However, in these regions, the direction of kangin continues to change according to the location of the villages. The further away from Seraya Village (the counter-clockwise movement), the direction to miss moving continues to be northward parallel to the coastal landscape, such as in Banyuning and Batukaseni. In these villages, kangin is to the north while the sun rises in kelod (towards the sea) (Wassmann \& Dasen, 1999).

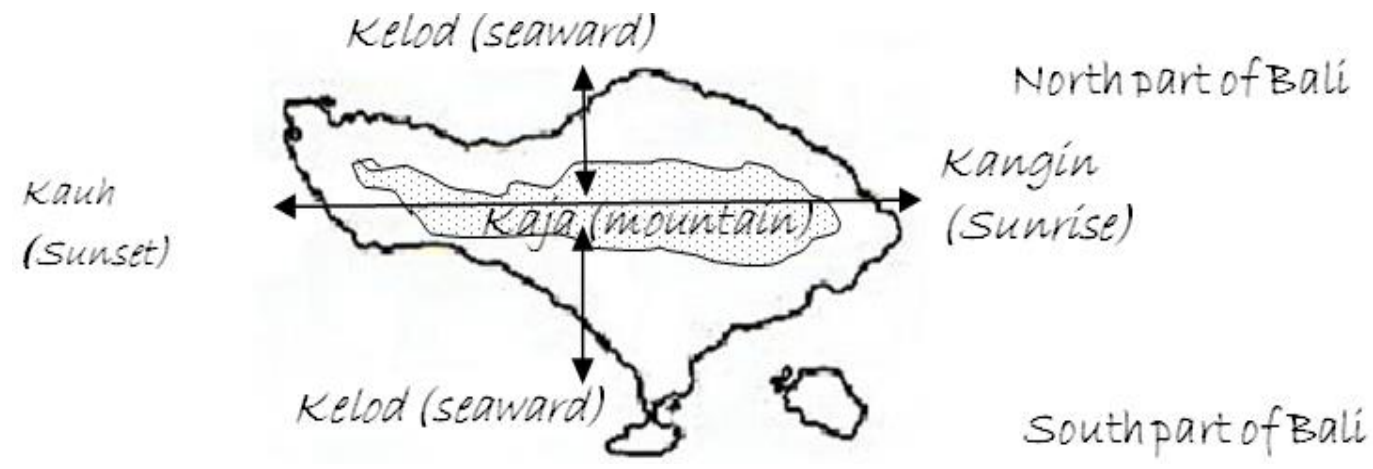

Figure 2. The two opposition concept, kaja-kelod and kangin-kauh in most villages in Bali (Source: Budiharjo, 1986)

In the variation of the village orientation, there is general concept of the Balinese village called desa pekraman. Unlike in the modern perspective that focuses on the numbers of the population (Smerdon et al., 1997), in Bali, the term "village" is about territory and congregation. A Balinese village is an organization of people living in a particular territory as members of a village (krama desa). They discuss, prepare and conduct many village ceremonies and festivals to maintain the sanctity of their village (Sukawati, 2004; Parimin, 1986). The unity of villagers is related to karang desa, the area of dwellings of villagers; awig-awig, the rule that is made and imposed to villagers; and kahyangan tiga, the three temples (Puseh, Desa and Dalem) as a system of temples for villagers for praying (Pitana, 1994). A village has the autonomy to manage its area in cultural and religious activities. It also has and creates its own traditional rules (awig- 
awig) and elects a head of a village called bendesa. Any decisions and policies in the village are stated in a meeting of members. Usually, a village is divided in some traditional neighborhood communities called banjar. This traditional village system is handed down from Balinese ancestors. However, in order to address novel conditions, the new system has been created to complete the old. The old called desa pekraman still managed religious and traditional practices while the new managed secular activities. These two systems have been applied since the Dutch administration in Bali and are still applied until today (Vickers, 1989; Picard, 1996; Nordholt, 1986). Therefore, desa pekraman is more "a ritual -symbolical entity than a practical administrative one" (Warren, 1993, p. 7).

However, the engagements with other cultures and the novel condition of social movements have influenced the process of cultural transformation in Balinese communities. The transformation that profoundly influences the process of accepting new traditions in many parts of Bali has been stated by many studies on Bali such as those of Agung (1991), Dharmayuda (1995) and Picard (1996). These factors cause the variation of not only the process of inheritance of traditions but also acceptance and recommendations, based on the various motives of recipients. This process varies in every society to produce a variety of cultural practices. This variation can be presented in the traditional Balinese houses influenced by the variation of the villages. The villages are divided into two types, namely the Bali Aga and Bali Daratan. The first mostly lay in the highland areas, while the second that are the majority in Bali are influenced by the Majapahit culture (Parimin, 1986). Under the external force of the Majapahit cultures, the Balinese culture has been transformed. This transformation is the result of both conquest and colonialism. The transformation has also undergone until today in which the Balinese culture is also influenced by Tourism Economy (Putra et al., 2019).

The Bali Aga villages are few in numbers. However, they have various local traditions. The main characteristic of this village is a communal street running from kaja (toward the mountain) to kelod (toward the sea) such as Julah, Tenganan and Bugbug (Figure 3). However, every Bali Aga village has a specific pattern (Parimin, 1986).

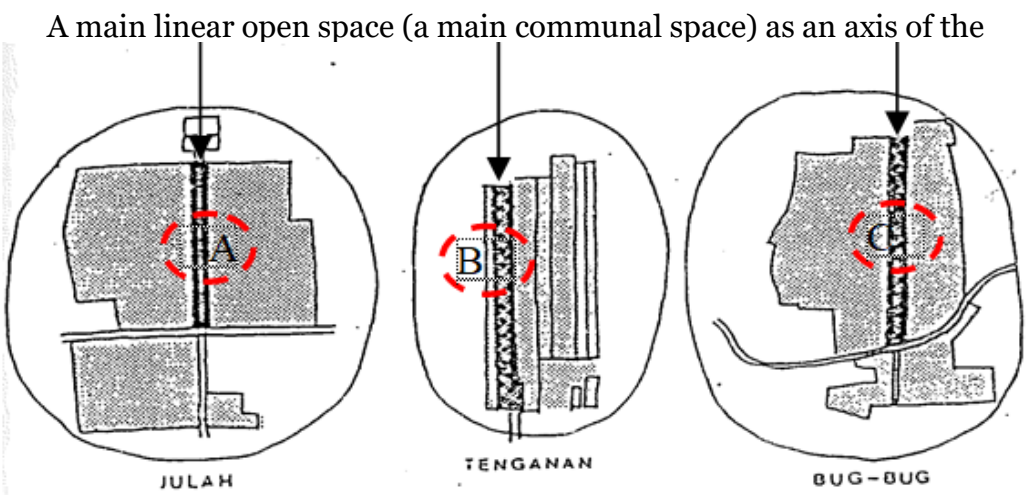

Figure 3. Plans of Bali Aga villages (Julah, Tenganan and Bugbug), (Source: Parimin, 1986)

The main physical feature of the Bali Aga village is a linear communal open space consisting of various facilities. This space is significant in the village to perform social and ceremonial practices as communal activities. The communal space in Tenganan, for example, consists of temples; ayunan, a traditional swing; bale agung, a meeting hall of the village; bale kulkul, a wooden bell tower; jineng, a typical rice granary; bale lantang, a place for performing ceremonial activities and bale teruna, a meeting hall for the youth 
(Samadhi, 2004). In contrast, the Bali Dataran villages that are influenced by Majapahit culture have few village facilities. The pattern is similar because of cultural standardization by the Gelgel Kingdom, which is the inheritor of the Majapahit Kingdom from Java in Bali. The pattern of the village has copied the Majapahit prototype (Parimin, 1996). Based on Majapahit system, a village is divided by two main axes (kaja-kelod and kangin (east) -kauh (west)) called catus patha (Figure 4). Spaces around the crossroad are locations of some village facilities including a market, temples, and $a$ community meeting pavilion called wantilan. In these spaces, villagers carry out ceremonial and traditional practices including many ceremonies and social activities.

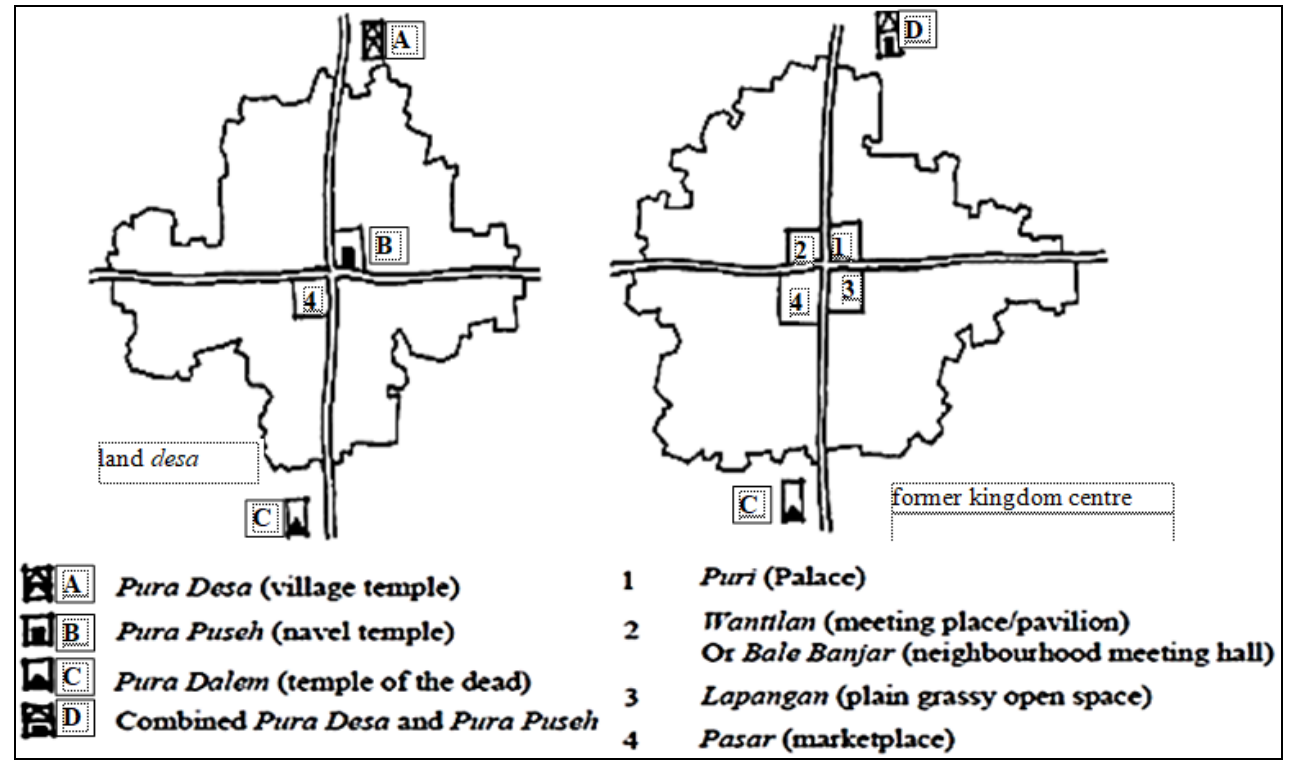

Figure 4. Plans of Bali Dataran villages (Source: Parimin, 1986)

On the other hand, unlike most villages in southern and northern Bali, villages in the eastern part of Bali, especially the villages around mount Bisbis such as Culik, Bangle, Sega, Amed and Bunutan, have different local spatial orientation systems in every village (Wassmann \& Dasen, 1999). In this area, the orientation system uses mount Agung as the peak point for kaja direction if the mount is visible from the village such as Culik and Amed. However, if the mount Agung is invisible, the orientation for kaja is toward another mountain nearby such as Mount Bisbis and Seraya. Both mountains are small and not too high but have a particular value for both villages. While in southern of Bali, $k a j a$ is the north and kangin is the east, in Sega, kaja is north-east direction and kangin is almost east while in Bangle the next village, kaja is south-west and kangin is south-east. In Amed, kaja is west and kangin is south while in Bunutan, kaja is the south-west while kangin is east (Figure 5) (Wassmann \& Dasen, 1999).

\section{MATERIALS AND METHODS}

Factors that influence the pattern of a traditional village and settlement are spatial orientation that has been used for generation to generation. The orientation influences the zonation and the way people perform their socio-cultural and domestic activities. This paper used the architectural and historical investigation as an essential method of 
examination. This method involved architectural documentation, graphic analysis, spatial stories of people's and narratives of people's cultural activities and traditions to produce the inventory of spaces in the settlements. This inventory was an essential stage to examine physical characteristics of the settlement that can carry out through a based line survey. This based line was undergone to record and explore the pattern of the settlement and housing. Physical transformations of the village were documented and examined through visual investigation. This inventory and interviews with the occupants are the way to reconstruct the unique and specific pattern of the traditional settlement and houses in this area (Putra et al., 2017). This paper has identified three villages (Culik, Sega and Amed) as case studies for the examination of the variation of the spatial orientation and the pattern of the traditional village as a new tourist attraction in the Eastern Bali. The patterns of the villages are varied. The variations depend on the spatial orientation that is oriented to the mountains that have an essential meaning.

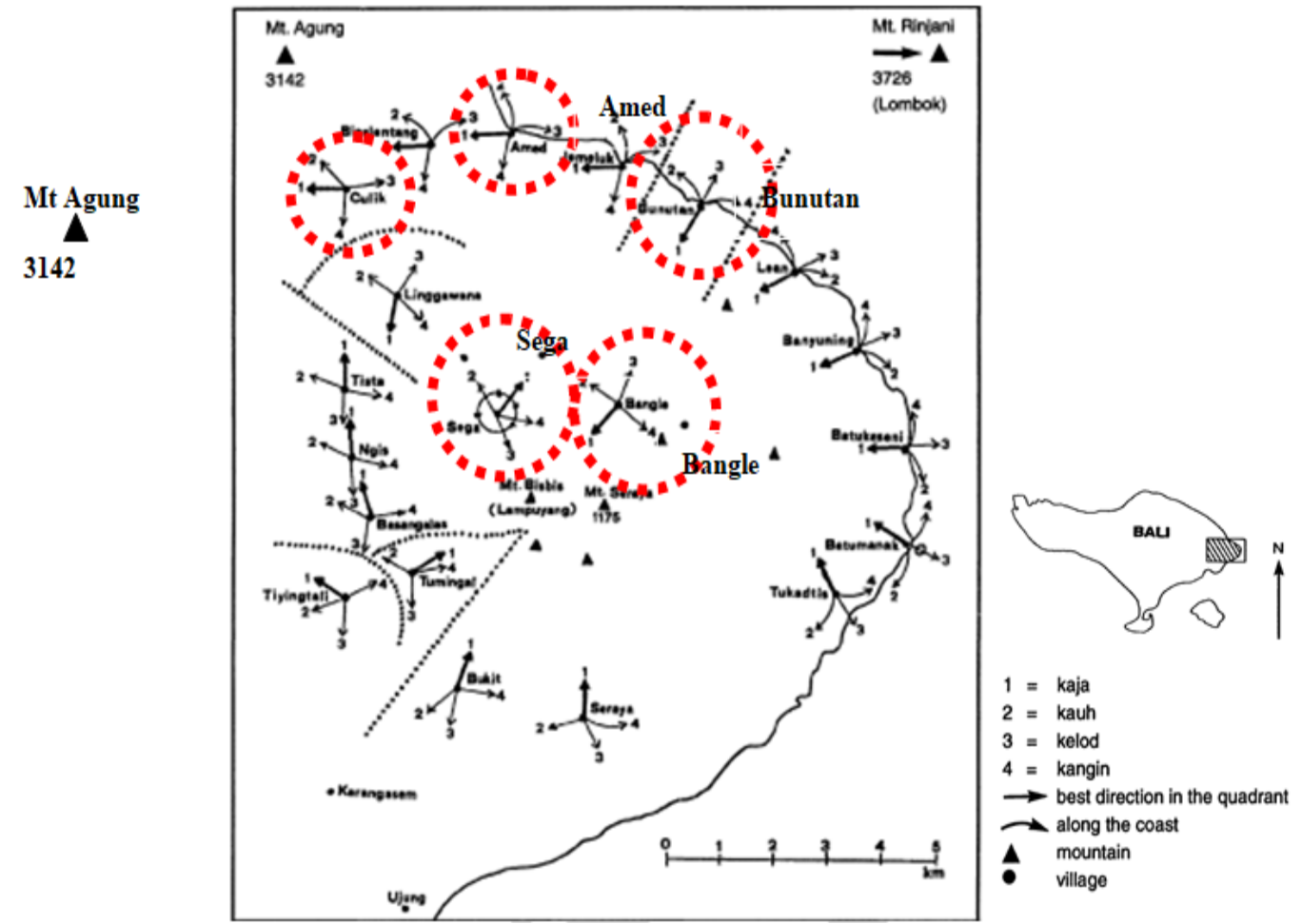

Figure 5. Traditional orientation system in many villages in Eastern of Bali

(Source: Wassmann \& Dasen, 1999)

As an architectural production, the patterns are cultural products that express the sameness of the members of society. Amed is located in the east of Mount Agung, the most important mount in Bali. Since the mount is visible from the village, the mountain is believed as a sacred place for the people. Therefore, kaja in Amed is directed to the west (toward Mount Agung) while kelod in Amed is directed along the coast and kauh towards the sea. Similar to the first village, kaja in Culik is the West. However, when Amed is a beach village, the center of the Culik is a little bit far from the beach. On the other hand, Sega is a highland village. In this village, kaja is to the top of the slope. Spatial orientation 
produces a different pattern of the villages. In an attempt to capture this variation, the three villages, which have a different location, geographic condition and spatial orientation, were selected as the locations for this study. They are Amed that is a coastal village, Culik that is the center of the village is far from a beach and Sega is a highland village.

\section{A TRADITIONAL VILLAGE AS A STAGE OF CULTURAL TOURISM}

Villages and traditional houses can be seen as a stage to perform many ceremonial activities. Many festivals are performed in a temple and utilize many areas of the village during the ceremonial process. Melasti is one of the rituals during a festival in a temple that attracts visitors. This activity is dedicated to God in order to purify spiritual offerings. Villagers bring offerings and parade from a temple to either a river or a beach. Ngaben is another ceremony that is performed in both a traditional house and village facilities. This ceremony is performed in a house, and the families, helped by the villagers, bring a dead body to a graveyard using a tower building called wadah. Such activities are found in almost every village in Bali and become a cultural performance to attract tourists. Ceremonial practices that are dedicated to God, ancestors, the environment and human beings are also performed in a traditional house. These activities are performed in pavilions and natah (the courtyard).

The activities generally involve relatives, members of a village and friends to help the family to manage the practices. Similar to the ceremonies in the village, ceremonies in the traditional house also utilize many offerings. A culture consisting of artifacts and other cultural practices is a resource for tourism development in many regions, including Bali. The Balinese culture, inspired by the Hindu Balinese religion, is utilized as an asset by the Balinese. Tourism development has an interrelationship with culture.

Tourism has motivated the consciousness of the people to preserve their cultural practices because cultural preservation has supported tourism development (Sanger, 1989; McKean, 1973). Since the emerge of cultural tourism in the 1980s, the satisfaction of tourists in a tourism destination has been no longer enjoying the natural beauty and completeness of tourist facilities but also has tried to visit historical and cultural sites, attend special events, or visit museums (McKercher \& Cros, 2002). The uniqueness of the village patterns and the environment-friendly of the villages can be a new solution for tourism development (Susyanti \& Latianingsih, 2014). In cultural tourism, all elements in a village are potentials for tourist attractions. The village is a stage to perform its traditions, culture, environment and activities that are different from other villages.

\section{THE PATTERN OF THE SETTLEMENT AS TOURIST ATRACTIONS IN THE EASTERN OF BALI}

The variations of settlement in Bali can be seen as an idea of uniqueness that offers a sense of dignity. As an architecture production, the patterns of settlements are cultural products that express a commonality of tradition and culture among the members of a society and sharp distinctiveness, from non-members. The differences in the orientation system in the eastern part of Bali have influenced the variation of the pattern of the settlement. Since Mount Agung is located in the west of the village, kaja in Amed is directed to the west. The mountain is visible from the village so that the mountain is believed as a sacred place for the people. Unlike other villages in Bali that is kelod toward the sea, kelod in Amed is directed along the coast and kauh towards the sea. This orientation then is used as a reference to arrange spaces. Like other villages in Bali, the direction of kaja-kangin is a sacred area, while the profane zone is in the direction of kelod-kauh (Figure 6). Figure 6 also demonstrates that the village has one 
main axis that connects the Puseh temple (Figure 7a) to the cemetery with the graves where the houses of the residents are in between them. Every resident's house has an exit toward the main corridor. Some alleys are in the vicinity of the main corridor (Figure $7 \mathrm{~b}$ ) with several houses using the path as the primary access.

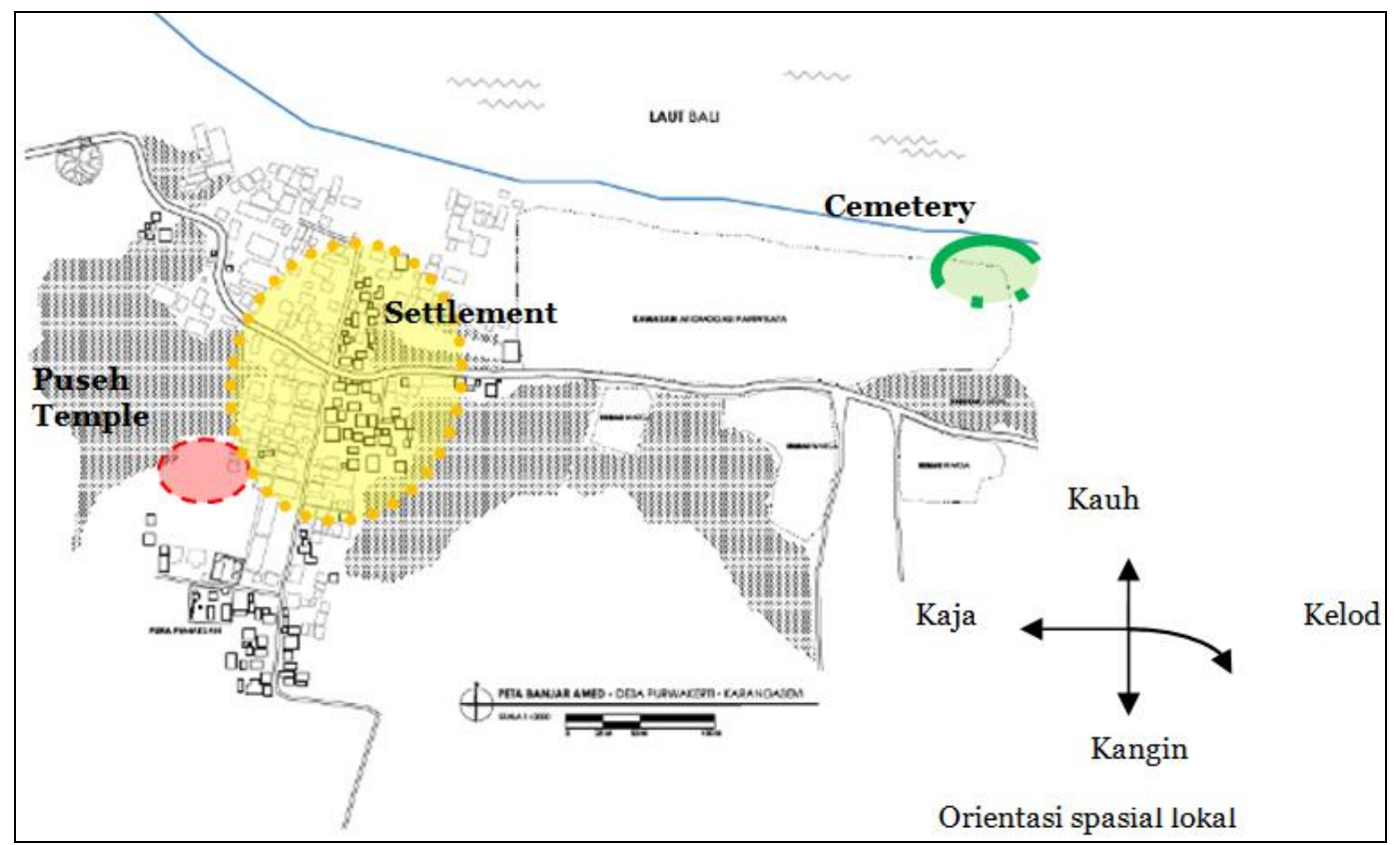

Figure 6. The pattern of Amed (Source: Modified from Satellite Image-Google Earth, 2019)

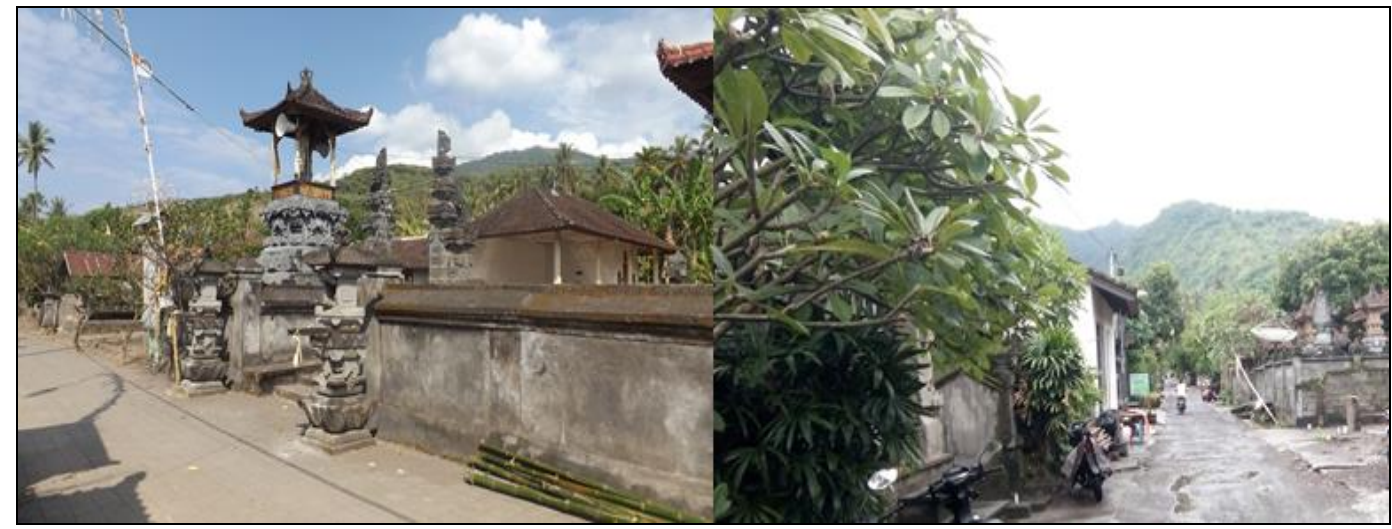

Figure 7. Puseh Temple (left) and the corridor of Amed (right)

Similar to Amed, Mount Agung is visible from Culik so that the most sacred place is directed to kaja (west). In this village, the center of Culik traditional village facility is Bale Agung temple that is the center of the cultural activities of Culik. The zoning of the main functions in Culik uses local spatial orientation where the direction of kaja is a sacred area and the location of a holy place, while the profane zone is in the direction of kelod (Figure 8). The village pattern, in general, is in the form of catus patha in the direction of 
kangin from Bale Agung temple (Figure 9a). In the direction of kangin-kauh there is a village market which then extends as a trading area around the catus patha extending along the road. In the middle of the catus patha, there is a statue of the goddess Danu which is related to the history of the village. The residential area stretches along the main path of the catus patha (Figure 9b). Each house has an exit toward the main corridor and there are several alleys where several houses access to the alley.

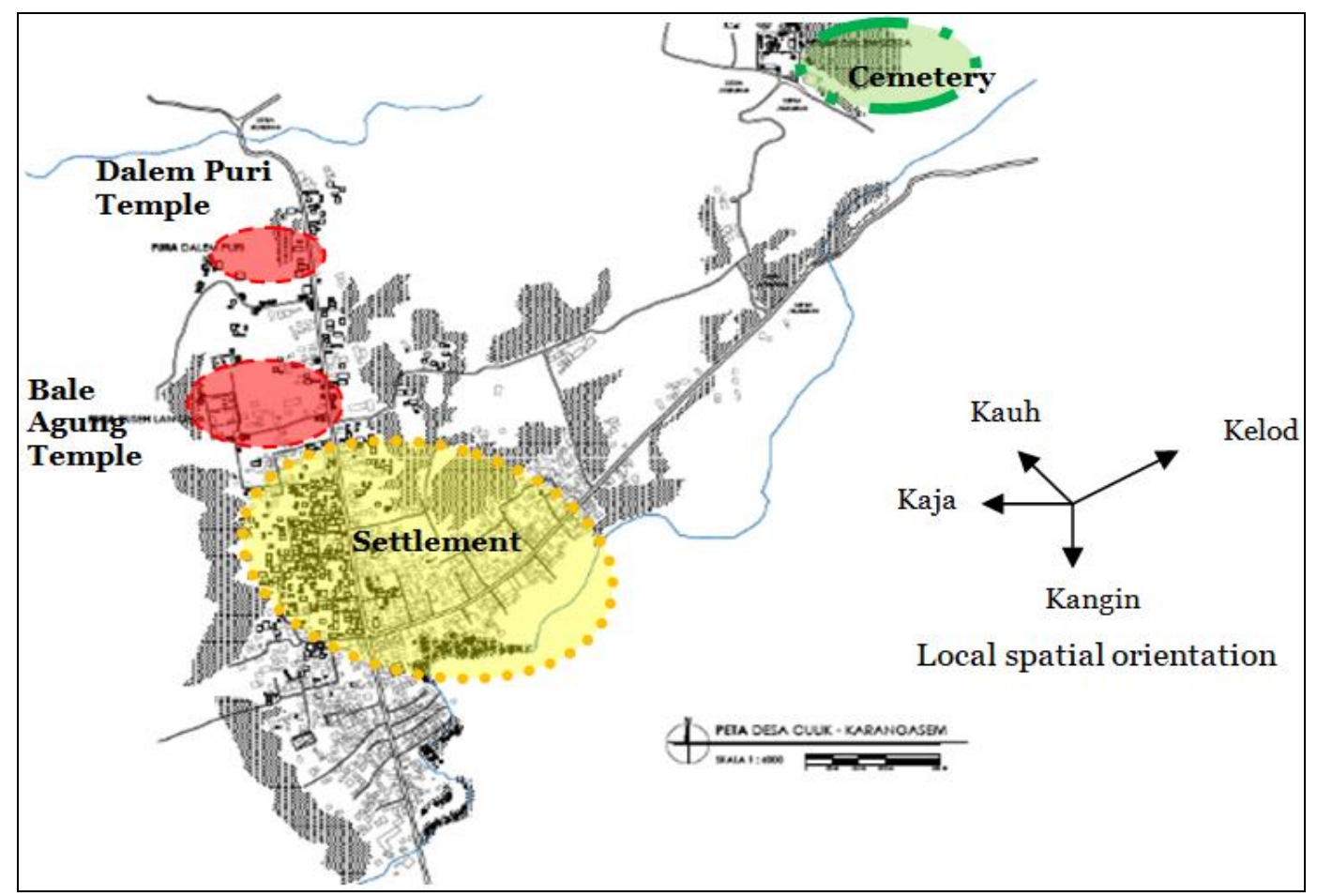

Figure 8. The pattern of Culik (Source: Modified from Satellite Image-Google Earth, 2019)

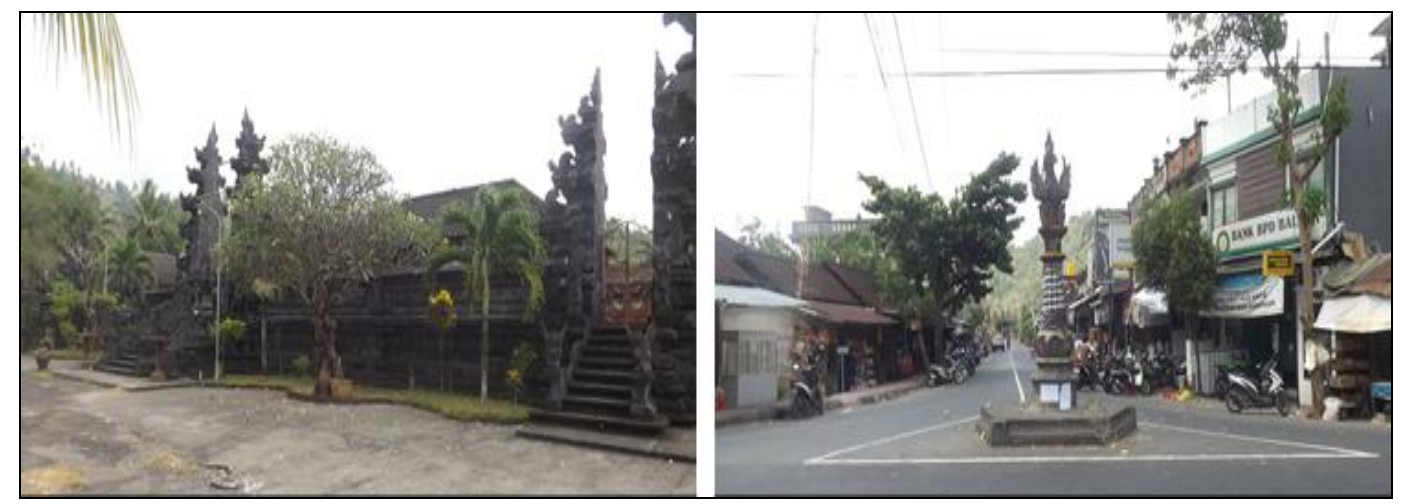

Figure 9. The Bale Agung Temple (left) and the catus patha (right) of Culik

The difference between the other two villages, Sega is a traditional village that has an extensive area with the village center is in a plateau. In Sega, kaja designates the top 
of the slope on which the village lies. On the other hand, kelod is directed toward Mount Bisbis (Lempuyang) while kangin is towards sunrise. The uniqueness of this village is that the sacred place is located at upstream location called hulu that is at the direction of kauh (north-west) (Figure 10). The abovementioned local direction then influences the setting of the village. The main temple in Sega (Bale Agung and Puseh Temple) is located in hulu direction not in kaja like other villages (Figure 11a). Around the temple, there are also several kawitan temples, the temple for a kinship group. Meanwhile, the cemetery is in the direction of teben (profane direction). Residents' housing is more or less from the sacred area where people's houses lead to the main road. The settlement has two main corridor lanes where each resident's house puts the gate towards the corridor (Figure $11 \mathrm{~b}$ ). Several houses use small alleys as access to the main corridor. In the past, this corridor had access to the village to other villages.

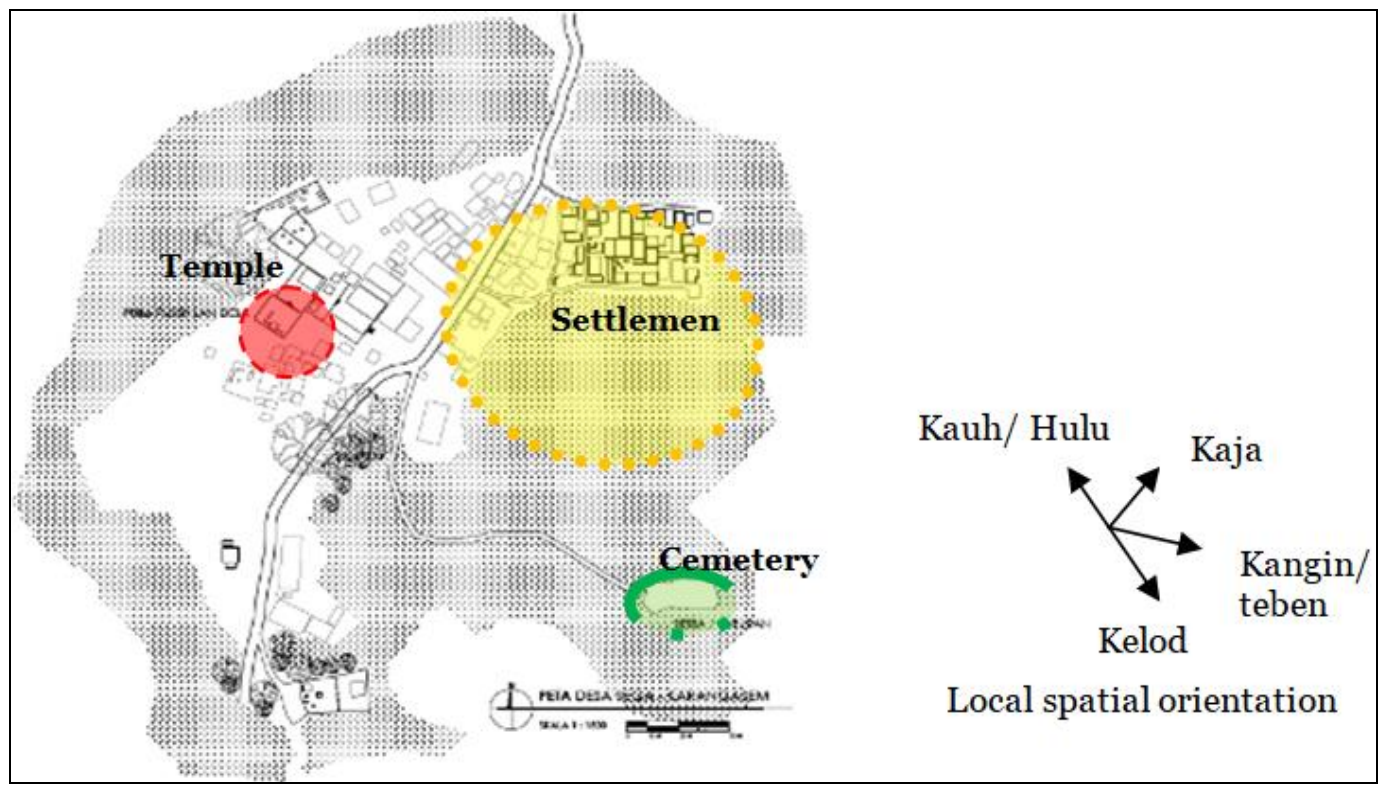

Figure 10. The pattern of Sega (Source: Modified from Satellite Image-Google Earth, 2019)

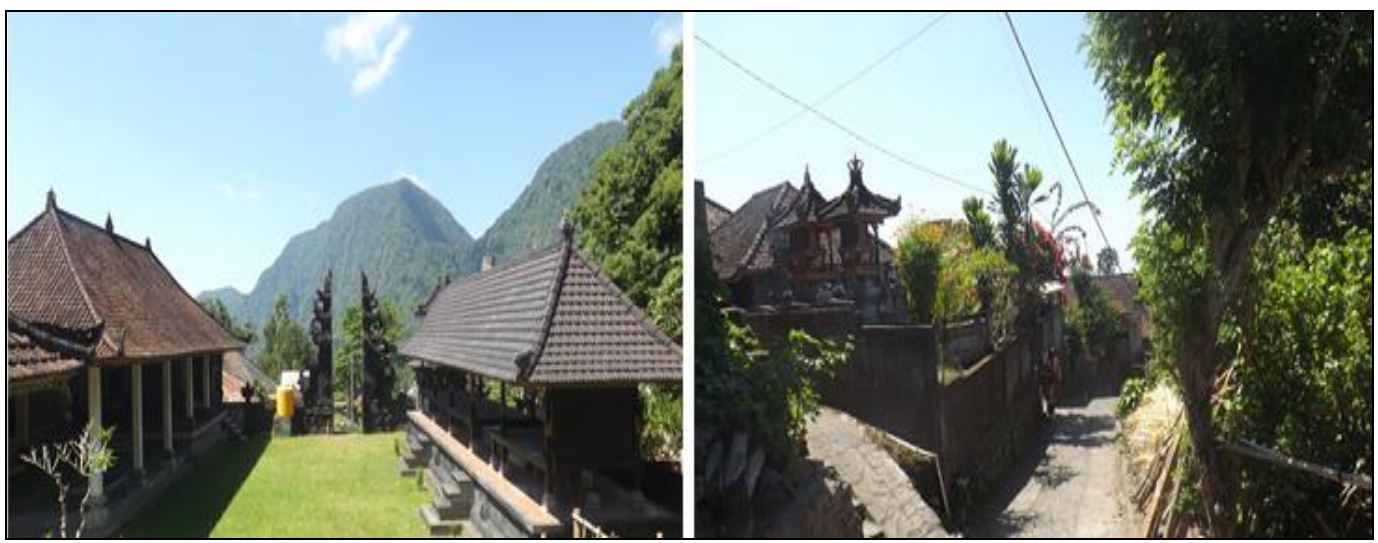

Figure 11. The Bale Agung and Puseh temple (left) and the corridor (right) of Sega 
The differences in spatial orientation have produced the differences and variations of the patterns. Since Bali has relied on its culture to develop the unique tourism model, these variations have become the resources of tourism development to attract tourists. The motivation of tourists is not only to look for the natural environment but also to search for exotic cultural experiences (Yang et al., 2006) that are known as cultural tourism. This phenomenon is inspired by cultural motivations such as performing arts, cultural trips, and other related activities (World Tourism Organisation, 2012). Based on this motivation, many regions try to preserve their culture and promote them to generate traveler attention (Yang \& Wall, 2009). Bali, as the main traveler destination in Indonesia, accentuates its culture to be a magnet for tourism. However, tourism in Bali is separated into two, ("sunlust" and "wanderlust"). Gray (1970) stated "sunlust" is tourists motivated by the desire for rest and relaxation at the three "s" (sun, sea and sand) (Heitmann, 2011, p. 33). On the other hand, "wanderlust" is tourists who travel and are interested in different traditions and cultures. A motivation of tourists to experience different cultures gives opportunities to the villages around Mount Bisbis (Lempuyang) in the eastern part of Bali that have variations of spatial orientation and settlement patterns to develop their unique tourism models. These variations will produce the variations of cultural activities and practices in which the spaces in a village become the theater of the cultural activities. The spaces on the settlement can be seen as a stage to perform many ceremonial activities. The uniqueness of the settlement, including the spatial pattern of the village and the use of spaces in performing socio-cultural activities, can create new tourism products. These opportunities are influenced by the guests' motivation for authenticity, which is fundamentally a quest for cultural diversity (MacCannell, 1976). As a part of the culture, the uniqueness of culture becomes a strategy to seize opportunities in the development of tourism products (Sugiyarto \& Amaruli, 2018). The significant role of cultural diversity for attracting tourists may help to preserve cultural practices (Cohen, 1988). The uniqueness of a tourism product, including cultural and ceremonial activities, architectural styles, traditional houses and traditional settlement and pattern, should be evoked and utilized as resources to attract tourists.

These unique resources should be conserved for continuous use in the future, in which they are not only significant for the natural environment but also crucial for cultural identification (Schlüter \& Schumann, 2018). The original culture helps people to distinguish their uniqueness, in which a culture experiences a unique response of a community to face novel conditions, including the dynamic phenomenon of the tourism economy. The response is an ongoing process and historically unfinished (Clifford, 1994; Salamone, 1997). In Bali, this process has been described as a "never-ending quest" or "a state of flux" in which the Balinese persistently transform their traditions to face novel circumstances and demands (Nordholt, 1986, p. v). Since tourism demonstrates an interest in local culture by presenting their unique culture artifacts, it presents new opportunities for preserving the uniqueness of local culture. The people in the eastern of Bali can confirm their settlement unique pattern and identity, including the unique spatial orientation and pattern. The villages, in which domestic and ceremonial practices are performed, have opportunities to be used for tourist facilities. Even though there are some negative impacts of tourism on their unique culture (Hanna, 1972; Bugnicourt, 1977; Picard, 2003; Achmadi, 2007), tourism can support cultural preservation.

Its development has motivated the consciousness of local communities to maintain the uniqueness of their culture (Sanger, 1989; Dogan, 1989). Therefore, the use of unique culture, such as traditional settlement pattern, as a tourism asset provides a more suitable model for tourism development in eastern part of Bali. However, local communities 
should be aware the sustainability of their culture that is related to the ability to resist the negative impact and preserve the genuineness of the culture.

\section{CONCLUSIONS}

There are variations of the pattern of the traditional Balinese settlement, including those in the eastern of Bali. The orientation of most villages in Bali is northsouth as the main axis. This direction traditionally is a kaja-kelod. However, in the eastern of Bali, the kaja is centered into the peak of Mount Bisbis or Seraya, so that way, the directions differ from one village to another. This direction causes variation in the pattern of settlements in this region. These variations become the resources of tourism development because Bali has relied on its unique culture to attract tourists.

This technique is used because the motivation of tourists is not only to the desire for rest and relaxation but also experience different people and cultures. This motivation gives opportunities to the villages, which have variations of spatial orientation and settlement patterns, to develop their unique tourism models.

The uniqueness of the settlement patterns can be used as an approach appealing to tourists to manage the village as a place not only to perform domestic and sociocultural practices but also to gain economic benefit from tourists. The villages that used to be only a place to perform domestic and socio-cultural activities now can also have a new additional function called tourist activities. The trading activities, which used to be just in a market, today can also take place in many places in the villages, including the houses, main core of the villages and rice fields. Since tourism demonstrates an interest in the local culture, it presents new opportunities for local communities to use their culture as an asset to attract tourists. This model also becomes an opportunity for increasing the people's awareness to preserve and maintain the uniqueness of their culture.

\section{Aknowlegments}

We want to send our gratitude to the Indonesian Government for research funding. We also offer a deep-felt thanks to colleagues and friends at Udayana University and elsewhere who offered spirited discussion and critical feedback. I also thank the students of the Department of Architecture, Udayana University, Bali, assisting me during fieldwork in the Eastern of Bali.

\section{REFERENCES}

Achmadi, A. (2007). The architecture of Balinisation: writings on architecture, the villages, and the construction of Balinese cultural identity in the 2oth century, Ph. D. thesis, the University of Melbourne, Australia.

Agung, I.A.A.G. (1991). Bali in the 19th century, Jakarta: Yayasan Obor Indonesia.

Brubaker, R. \& Cooper, F. (2000). Beyond identity, Theory and Society, vol. 29, no. 1, , pp. 1-47.

Budiharjo, E. (1986). Architecture conservation in Bali, Yogyakarta: Gajah Mada Univerity Press.

Bugnicourt, J. (1977). Tourism with no return, The Bridge, vol. 2 no. 4, pp. 19-20.

Clifford, J. (1994). The Predicament of Culture: Twentieth-Century Ethnography, Literature, and Art, Harvard University Press, Cambridge.

Cohen, E. (1988). Authenticity and commoditisation in tourism, Annals of Tourism Research, vol. 15, issue 3, pp. 371-386.

Derek \& Japha, V. (1991). 'Identity through detail: an architecture and cultural aspiration in Montagu, South Africa, 1850-1915', TDSR, vol. II, pp. 17-33.

Dharmayuda, I.M.S. (1995). Kebudayaan Bali: pra Hindu, masa Hindu dan pasca Hindu, Denpasar: CV Kayumas Agung.

Dogan, H.Z. (1989). Form of adjustment social impact of tourism, Annals of Tourism Research, vol. 16, issue 2, pp. 216-236. Eiseman Jr, F. B. (1989). Sekala and niskala: essays on religious, ritual and art, vol. I, Periplus Editions, Singapore.

Salamone, F. A. (1997). Authenticity in Tourism: The San Angel Inns, Annals of Tourism Research, Vol. 24, No. 2, 305-321, 1997

Gelebet, I.N. (1986). Arsitektur tradisional daerah Bali, Denpasar: Departemen Pendidikan dan Kebudayaan. Gray, P. (1970). International Travel-International Trade. Lexington, Massachussets: Heath Lexington Books. 
Gupta, T. (2017). The Pgycho-spiritual Spaces for Human Settlement, International Journal of Civil Engineering and Technology (IJCIET), vol 8 (5), pp. 1290-1294.

Hall, S. (1990). 'Cultural identity and diaspora', in J Rutherford (ed), Identity, community, culture difference, Lawrence and Wishart, London, pp. 222-237.

Hanna, W.A. (1972). Bali in the seventies, part I: cultural tourism, American Universities Field Staff Reports, Southeast Asia Series, vol. 20, no. 2, pp. 1-7.

Heitmann, S. (2011). Tourist behaviour and tourism motivation, in P Robinson, S Heitmann \& P Dieke (eds), Research themes for tourism, CAB International, Oxfordshire UK, pp. 31-44.

Hobart, A., Ramseyer, U. \& Leemann, A. (2001). The people of Bali, Massachusetts: Blackwell Publishers Ltd., 2001.

Lozanovska, M. (2011). Holy days after migration, 2nd International Conference on Intangible Culture, Green Lines Instituto, Barecelos, pp. 459-469.

MacCannell, D. (1976). The Tourist: A New Theory of the Leisure Class. New York: Shocken

McKean, P.F. (1973). Cultural involution: tourists, Balinese, and the process of modernization in an anthropological perspective, Ph. D. dissertation, Brown University.

McKercher, B. \& Cros, HD. (2002). Cultural tourism: the partnership between tourism and cultural heritage management, the Hawrth Hospitality Press, New York.

Meganada, I.W. (1990). Pola tata ruang arsitektur tradisional dalam perumahan KPR-BTN di Bali', Magister thesis of architecture, Institut Teknologi Bandung.

Nordholt, H.S. (1986). Bali: colonial conceptions and political change 1700-1940 from shifting hierarchies to 'fixed' order, Erasmus, Rotterdam.

Parimin, A. P. (1986). Fundamental study on spatial formation of island village: environmental hierarchy of sacred-profane concept in Bali, Ph.D. dissertation, University of Osaka, Osaka.

Picard, M. (1996). Bali: cultural tourism and touristic culture, Singapore: Archipelago Press.

Picard, M. (2003). Touristification and Balinization in a time of reformation, Indonesia and the Malay World, vol. 31 , no. 89 , pp 108-118.

Pitana, I.G. (1994). Dinamika Masyarakat dan Kebudayaan Bali, Penerbit Bali Post, Denpasar.

Proshansky, H.M., Fabian, A.K. \& Kaminoff, R. (1983). 'Place identity: physical world socialization of the self', Journal of Environmental Psychology, vol. 3, pp. 57-83.

Putra, I.D.G.A.D., Lozanovska, M. \& Fuller, R. J. (2019). From Spiritualistic toward more Pragmatic Pattern: Re-ordering Balinese Houses and Viability of the Household Traditions in Tourism Economy, Journal of Architecture and Urbanism, vol 43 (1), pp. 47-61.

Putra, I.D.G.A.D., Lozanovska, M. \& Fuller, R.J. (2017). A Metodology to Evaluate the Transformation of Traditional Balinese Houses as a Consequence of Tourism, International Journal of Architecture Research (Archnet-IJAR), vol 11 (1), pp. 83-100.

Rigg, J (1996). The human environment, volume 2 of Indonesian heritage, Archipelago Press, Singapore.

Samadhi, T. N. (2004). Making cosmo-religious landscapes: the design of a Balinese town's civic center (Bali, Indonesia), Habitat International, 28, pp. 103-122.

Sanger, A. (1989). Music and musicians, dance and dancers: socio-musical interrelationships in Balinese performance, Yearbook for Traditional Music, vol. 21, pp. 57-69.

Schlüter, T. \& Schumann, A. (2018). Geosites as a Potential for the Development of Tourism - Overview of Relevant Sites in Eswatini (Formerly Swaziland), GeoJournal of Tourism and Geosites, Year XI, vol. 22, no. 22, pp. 535-547).

Smerdon, T., Waggett, W. \& Grey, R. (1997). Sustainable housing: options for independent energy, water supply and sewerage, the Building Service Research and Information Association, Berkshire.

Sugiyarto \& Amaruli R. J. (2018). Pengembangan Pariwisata Berbasis Budaya dan Kearifan Lokal, Jurnal Administrasi Bisnis, vol. 7, no. 1, Maret 2018, pp. 45-52).

Sukawati, T.O.A.A. (2004). Ubud bergerak, CV Bali Media Adhikarsa, Denpasar.

Susyanti, D.W. \& Latianingsih, N. (2014). Potensi Desa Melalui Pariwisata Pedesaaan, Epigram, 11 (1):65-69

Swellengrebel, J.L. (1984). Introduction, in JL Swellengrebel (ed), Bali: studies in life, thought, and ritual, Foris Publication Holland, Nethelands, pp. 1-76.

Vaisakh, B. \& Sood, S. (2017). Tribal Settlement in Wayanad Kerala, International Journal of Civil Engineering and Technology (IJCIET), vol 8 (5), pp. 1316-1327.

Vickers, A. (1989). Bali: a paradise created, Ringwood Victoria: Penguin Books Australia Ltd.

Warren, C. (1993). Adat and dinas, Balinese communities in the Indonesia state, Oxford University Press, Kuala Lumpur.

Wassmann, J. \& Dasen, P. R. (1999). Balinese Spatial Orientation: Some Empirical Evidence of Moderate Linguistic Relativity, The journal of the Royal Anthropological Institute, vol 4, No. 4, pp. 689- 711.

Yang, L. \& Wall, G. (2009). Ethnic tourism: a framework and an application, Tourism Management, 30, pp. 559-570.

Yang, L., Wall, G. \& Smith, S.L.J. (2006). 'Ethnic tourism development: Chinese Government perspectives', Annals of Tourism Research, vol. 35, no. 3, pp. 751-771.

*** World Tourism Organization (2012). World Tourism Barometer, vol. 10.

Submitted:

24.12.2019
Revised:

20.04.2020
Accepted and published online 27.04.2020 